\title{
Determining Innovation Aspect in the Performance of Public Service Sector
}

\author{
*Qaanita Yuuha Mustafid, Grisna Anggadwita \\ Bandung Institute of Technology, Indonesia \\ *qaanita.yuuha@sbm-itb.ac.id
}

\begin{abstract}
Innovation is important for organizational survival, not only for private company but also for Public Service Company. When the private company needs to develop innovation to win the market competition, public service sector develops innovation in order to increase efficiency and public service quality. In order to evaluate and develop the successful innovation, the company needs to measure innovation performance. The purpose of this paper is to develop a framework for measuring innovation performance in the public service sector. This paper also identified the variables associated with innovation performance measurement in the public service sector. Using qualitative methods, we developed a performance measurement framework based on the literature review of innovation and performance measurement. The measured variables consist of inputs for innovation, innovation processes, innovation outputs, and the outcomes of implementing innovation. This research is expected to contribute to the literature used by academics and companies that have similar characteristics to measure innovation performance.
\end{abstract}

Keywords: Innovation, Innovation Performance, Innovation Performance Indicator, Performance Measurement Framework, Public Service Sector

\section{Introduction}

Albury (2005) gave the definition of successful innovation as "the creation and implementation of new processes, products, services and methods of delivery which result in significant improvements in outcomes efficiency, effectiveness or quality of outcomes". An organization must develop its innovation capabilities to survive in the fierce market competition. The public sector is an organization that tends to be static in fostering innovation, in contrast to the private sector that competes to produce innovations for customer satisfaction and sustainability of their organization. Currently, the public service sector still at the beginning phase to realize the importance of innovation as a key to an organization's success in winning the competition. The government-owned company also faced pressure to reduce cost and maximize the output. Citizens continuously wish a better and more effective public service. Some of the government public service also competes with other private organizations. For example, the government railway company in Indonesia also competes with other public transportation. In 2012, Indonesian government gave appreciation for the stated-owned companies that developed its innovation (statedowned company award - BUMN Award). This event was held to encourage the companies to constantly develop innovations to increase the competitive advantage. Public service basically is a state-owned company funded by government and no venture capitalists (Borins, 2001). Hence, the budget for implementing innovation is limited. Some of the state-owned company also reluctant to do an innovation because of the conservative mindset.

According to Neely et al (2005), the effectiveness and efficiency of activity can be evaluated with the conducted performance measurement. Measuring innovation performance will enable public service companies to trace their activities to produce innovation. This evaluation will lead managers understand whether the innovation is effective, efficient or not working. They also can trace what is the cause of failure and success of an innovation. According APSII (2011) is important that a public sector organization regularly review its innovation performance and develop a strategy to improve its performance and enhance its innovation capacity. This paper presents a framework for measuring innovation performance in the public service sector. This conceptual framework is based on a literature review of innovation and performance measurement in public and private sector. This paper started from presented the general definition of innovation and the difference between innovation in public and private sector. Then we discussed about the previous research of performance measurement, especially 
in the public service sector. Furthermore, we developed a framework for measuring public service innovation based on literature review. The framework was created based on innovation activities.

\section{Literature Review}

Innovation: Saunila \& Ukko (2012) defined innovation as "a new issue that creates value to the firm or stakeholders". The basis of innovation does not have to be a completely a new idea. It has to be new for the organization applying it. The Oslo Manual (OECD/Eurostat, 2005) defined innovation in four type new implementations of product (good or service), process, marketing method, and organisational method. NESTA (2008) defined innovation as something that "change associated with the creation and adoption of ideas that are new-to world, new-to-nation/region, new-to-industry or new-to-firm". Implementation, success, degree of change required, and sources of innovation are the four key elements in defining innovation (Bloch, 2010). Innovation can also be used to deal with new problems where existing techniques are unable to provide a solution, or apply a new method to a long-standing problem that has gone unsolved. According to Albury (2005), there is some type of innovation. Radical innovation is the development of new services or a fundamentally new way of organizing and delivering a service. Discontinuous or disruptive innovation is the type of innovation that required fundamental changed in organizational, social and cultural arrangements to have a full impact. While, incremental innovation is a minor change and adaptations to existing services or processes to improve performance. Bloch (2010) differentiated the type of public sector innovation as service innovation, process innovation, organizational innovation and communication innovation.

Innovation in Public Sector: According to APSII (2011), there is a difference between innovation in the private sector and public sector. Innovation in the private sector is driven fundamentally by profit whereas, public sector innovation concerned with the welfare of society. The barriers that public sector faced to make innovations are the fear of failure, the reluctance to change, along with the lack of incentive to innovate because of a limited budget. NESTA (2008) stated that the outcomes of the private sector improvements mean increased profits or market value, whereas in the public sector, it might mean to maximize the public value.

Performance Measurement: Neely et al. (2000) defined performance measurement as "the process of quantifying the efficiency and effectiveness of action". According to Radnor \& Barnes (2007), efficiency and effectiveness could be measured by input and output. So they also stated that the performance measurement could be evaluated from input, process and output of an activity. The measurement can be either quantitative or qualitative. Performance measures are important because it can be used to help managers focus on achieving results under its priorities. Performance measurement allowed a manager to identify the strengths and the weaknesses of their program and make adjustments accordingly (Steen, 2009).

Previous Research of Performance Innovation Measurement: There is still lack of a practical way to measuring innovation effectiveness and efficiency (Saunila \& Ukko, 2012). According to Muller et al (2005), currently, managers still unsure about the ability of the company to produce innovation. The manager still don't have the appropriate tool to evaluate the effectiveness and efficiency of their innovation program. Many other organizations assessed the innovation with traditional metrics of R\&D and product development (e.g. number of registered patents and percentage of sales as R\&D investment). Measuring performance must be appropriate with the objectives of the measurement itself (Steen, 2009). The first objective is to improve the government efficiency and effectiveness with innovation. Second, to develop the organizational culture that can encourage the creation of innovation. Muller et al (2005) gave two reasons the importance of measuring innovation performance. First, the measurement was based on the objective data which have a long term characteristic and risk related to innovation project. Second, the measurement helped to lead the company activities to keep align with their goals. The metrics to measure innovation performance was varied for every organization. This was because the difference of innovation capabilities for every organization. (Saunila \& Ukko, 2012).

Several frameworks in previous research (APSII, 2011; Bloch, 2010; Kolk et al, 2012; Muller et al, 2005; Saunila \& Ukko, 2012; Steen, 2009) used input, process and output variable to measure innovation performance in public and private sector. This was in accordance with Radnor \& Barnes (2007) notion that the performance measurement can be evaluated from input, process and output of an activity. 
Although it has the same variable, the indicator to measure innovation is varied because of the different definition of each variable. Steen (2009) explained the definition of each input, activity, output and outcomes in his research. Input as the resources that go into a project, including time, money and knowledge. Activity defined as the work that creates output. Output means the work that can be completed. Outcomes are the objectives of the project. Saunila \& Ukko (2012) created a framework to measuring innovation capability and its effect. They combined innovation capability framework and the balance scorecard framework. Innovation capability is defined as a variable that affected the capability of the organization to manage its innovation. This concept of innovation capability consisted of innovation potential (the potential that organizations have to produce innovations), innovation process (systems and activities fostering organizations to use their innovation potential), and result of innovation activities. Gama et al (2006) used the balanced scorecard for measuring value added by innovation, but it was lacking in measuring capability of innovation. Their framework only measured the financial aspect as the core of innovation. Some of the previous research (APSII, 2011; Bloch, 2010; EPSIS, 2012; NESTA, 2008; Steen, 2009) developed a framework for measuring innovation performance in public service. Steen (2009) divided the measurement into two aspects, impact of innovation and culture of innovation. However, there is some redundant indicator measured in both categories. Most of the previous research (Bloch, 2010; EPSIS, 2012; Kolk et al, 2012; Muller et al, 2005; OECD, 2005; Saunila \& Ukko, 2012; Steen, 2009) didn't examine the social and environmental aspect of implementing innovation, which is important to public service.

Table 1: Previous Research of Innovation Performance Measurement

\begin{tabular}{|c|c|c|c|c|c|}
\hline No. & Author & $\begin{array}{l}\text { Variable } \\
\text { Input }\end{array}$ & Process & Output/Result & Other Variable \\
\hline 1 & $\begin{array}{l}\text { Muller et } \\
\text { al (2005) }\end{array}$ & $\begin{array}{l}\text { Resource (capital, } \\
\text { labor, and time } \\
\text { that dedicated to } \\
\text { innovation), } \\
\text { Capability view } \\
\text { \% employees } \\
\text { who have } \\
\text { received training } \\
\text { in innovation), } \\
\text { Leadership (\% } \\
\text { employees for } \\
\text { whom innovation } \\
\text { is a key } \\
\text { performance } \\
\text { goal) }\end{array}$ & $\begin{array}{l}\text { Process } \\
\text { (innovation } \\
\text { markets, venture } \\
\text { funds, and } \\
\text { innovation } \\
\text { incentives) } \\
\text { Leadership } \\
\text { (senior leadersip } \\
\text { to support } \\
\text { innovation } \\
\text { process) }\end{array}$ & $\begin{array}{lr}\begin{array}{l}\text { Resource } \\
\text { return }\end{array} & \begin{array}{r}\text { the } \\
\text { investment }\end{array} \\
\text { strategic } & \text { in } \\
\text { innovation), } & \\
\text { Capability } & \text { view } \\
\text { (renewal number } & \text { new } \\
\text { of } & \text { nompetencies, } \\
\text { comper } & \text { of } \\
\text { number } & \text { strategic options), , } \\
\text { Leadership } & \text { (\% } \\
\text { employee } & \text { can } \\
\text { identity } & \text { the } \\
\text { innovation target) }\end{array}$ & \\
\hline 2 & $\begin{array}{l}\text { APSII } \\
(2010)\end{array}$ & $\begin{array}{l}\text { Investment in } \\
\text { Innovation, } \\
\text { Human resources } \\
\text { and } \\
\text { skills for } \\
\text { innovation, Staff } \\
\text { attitudes and } \\
\text { attributes } \\
\text { innovation, to } \\
\text { Sources } \\
\text { innovation, of } \\
\text { Technological } \\
\text { infrastructure for } \\
\text { innovation }\end{array}$ & $\begin{array}{l}\text { Diffusion of } \\
\text { innovation, } \\
\text { collaborations, } \\
\text { Innovation } \\
\text { management } \\
\text { practice, } \\
\text { Innovation } \\
\text { culture \& } \\
\text { Leadership, } \\
\text { Innovation } \\
\text { strategy }\end{array}$ & $\begin{array}{l}\text { Innovation } \\
\text { (activities } \\
\text { and } \\
\text { implementation), } \\
\text { Types of } \\
\text { innovation, } \\
\text { Innovation } \\
\text { novelty, } \\
\text { Innovation } \\
\text { intensity, } \\
\text { Intangible outputs } \\
\text { (e.g. trademarks, } \\
\text { copyrights) }\end{array}$ & $\begin{array}{l}\text { Outcomes } \\
\text { Societal and } \\
\text { environmental } \\
\text { impacts, Quality, } \\
\text { efficiency and } \\
\text { Productivity, } \\
\text { Improved } \\
\text { employee } \\
\text { Satisfaction, } \\
\text { Benefits for users, } \\
\text { Other intangible } \\
\text { effects } \\
\text { (e.g. trust and } \\
\text { legitimacy) }\end{array}$ \\
\hline No. & Author & $\begin{array}{l}\text { Variable } \\
\text { Input }\end{array}$ & Process & Output/Result & Other Variable \\
\hline
\end{tabular}




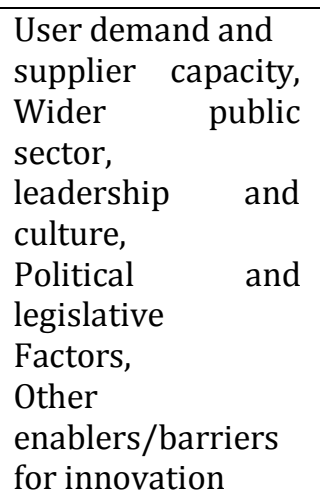

3 NESTA R \& D Activities, consultancy and strategic alliances, intangible assets, IT (2008) infrastructure, human resources, institutional performance: e-government online services, origins of innovations, innovation outputs, impact and scope.

4 Steen Measure in impact and culture of innovation, which is divided into input, (2009) activities, output and outcomes.

The previous model of measuring innovation performance had some strength and weaknesses. Therefore, this paper developed the new framework combined the variables from the prior research to complete it. Some previous research that used to develop our framework was described in Table 1.

\section{Methodology}

The objective of this paper is to develop a framework to measure innovation performance in public service sector. The framework was developed based on review of innovation performance measurement literature. First, we studied about the definition, type and characteristic innovation in public service sector. Then we examined the existing framework of innovation performance measurement, especially in public service sector. We analyzed and compared each variables and indicators from previous research. Afterwards, we developed a framework from combining previous variables and indicators.

Framework for Measuring Innovation Performance: In this paper, we used Saunila \& Ukko (2012) definition of innovation as the implementation of a new issue that creates value in the public service sector or stakeholder. Based on the previous literature review, we developed a framework to measure innovation performance into four variables: input, process, output and outcomes. Basically, we use APSII (2011) major framework (input, process, output, outcomes, environmental), but we take environmental condition into input variable as a stakeholder demand to create innovation. We also use the important characteristics for developing a culture of innovation that was stated by Borin (2001) as cited in Steen (2009). The variables are supported from the top, rewards and awards, resources, diversity learning from the outside, innovation involves everyone, experiment and evaluation, and use of teams. Support from the top is the important aspect to create the corporate culture focusing on innovation (Steen, 2009). Reward and awards are the appreciation that leader gave to encourage employees creating innovation. The resource is not only about fund, but also the availability of time and space. Diversity of workers and learning from outside help bring a new perspective and ideas. Creating innovation need the effort of everyone. The top leader supported the employee to think creatively and create new idea to improvement. Creating innovation is the responsibility of everyone. Experiment means trial and error to develop innovation (Borins, 2001). Evaluation means learning from the mistake and success, along with benchmark with other companies.

This framework is measuring innovation performance, both quantitative and qualitative. According Steen (2009) a solid performance measurement framework balances the used of both qualitative and quantitative methods. Qualitative measure is used to understand more deeply of a particular set of individual cases, to assess intangible concepts (e.g. perceptions on innovation, culture, skill, stakeholder impact), while quantitative measures aim to gain a clear understanding of a tangible variable (e.g. number of ideas that generate, time and money that have been spent to develop the concept or implementation, 
the number of innovations implemented). In this paper, we defined performance innovation measurement as measuring organization activities to produce an innovation, this also consisted of organization capability and the impact created by doing innovation (see Figure 1). According to OECD (2005), innovation activities include all activities that directed to implement innovation. This activity includes all organizational, financial, technological and scientific actions. We combined indicator from previous research and developed new variable name that can cover all (see Table 2).

Figure 1: Innovation Performance Measurement Framework

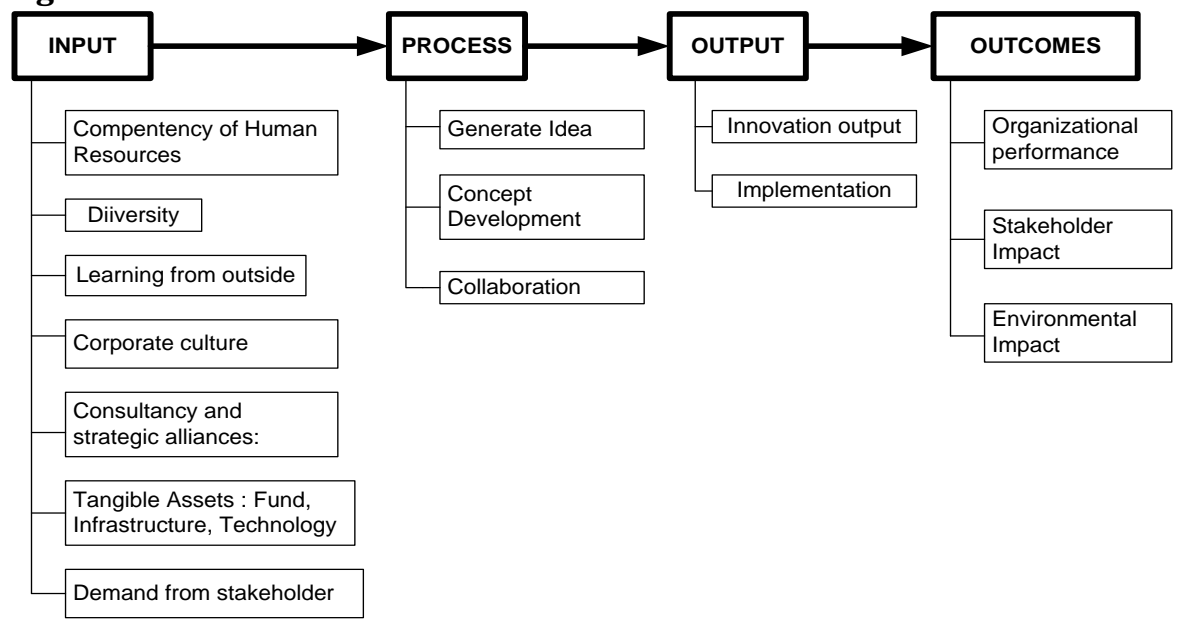

Table 2: Innovation Performance Measurement Variables

\begin{tabular}{ll}
\hline Variable & Factor \\
\hline Input & Competency of human resources (APSII, 2011; NESTA, 2008; Steen, 2009) \\
& Diversity (Steen, 2009) \\
& Learning from outside (Steen, 2009) \\
& Corporate culture (APSII, 2011; Borins, 2001; Muller et al., 2005; NESTA, 2008) \\
& Consultancy \& strategic alliances (NESTA, 2008) \\
& Tangible assets (Muller et al., 2005) \\
& Demand from stakeholder (APSII, 2011; NESTA, 2008) \\
& Generating idea (NESTA, 2008; Steen, 2009) \\
Process & Concept Development (Muller et al., 2005; Steen, 2009) \\
& Collaboration (APSII, 2011; Steen, 2009) \\
& Innovation output (APSII, 2011; Muller et al., 2005; NESTA, 2008) \\
& Implementation (Muller et al., 2005; NESTA, 2008; Steen, 2009) \\
& Organizational performance (APSII, 2011; NESTA, 2008; Steen, 2009) \\
Outcomes & Stakeholder impact (APSII, 2011) \\
& Environmental impact (APSII, 2011) \\
\hline
\end{tabular}

Input: In this framework, we defined input as factors that make it possible for the public service sector to create innovations. Creativity and diversity is needed to create an innovation (Albury, 2005). Creative thinking can be developed by providing such tools and facilities because it is not just a natural asset. Leadership is needed to direct the project to achieve the goal for the success of innovation. Top managers not always the pioneer of innovation (Borins, 2001). Employees at all levels can initiate the idea. According OECD (2005), some factors that hamper to create innovation are economic factor (high cost), lack of demand and employee skill or knowledge and government policy. Albury (2005) stated some factors that can stimulate innovation: budget for $R \& D$, rewards and support to adapt innovation, leadership action showed the importance of creating innovation, monitor and measure innovation systematically and create the innovation culture. From the literature review, we developed seven factors to measured innovation performance in input variable. 
1. Competency of human resources means employee capability to execute their task properly, such as their knowledge and skill. Human resources skill is broadly known as a centre of innovation (Bloch, 2010). This can be measured by the percentage of employees has graduate education and/or postsecondary education, number of training sessions that related to innovation, lists of subject training that related to innovation, list of subject training that can increase employee creativity (qualitative) (APSII, 2011; NESTA, 2008; Steen, 2009).

2. Diversity means the employee with different backgrounds working together, thus it can give a new perspective. According to Albury (2005), diversity helps to build creative tension, which is important in creating new and exciting ideas. Diversity can be measured by the diversity of education, backgrounds and experience employee and the unique team formed across the work units (Steen, 2009). The variety of backgrounds and ways of thinking developed the capacity of innovative (Albury, 2005).

3. Learning from the outside means employees learned from other organizations which also gave a new perspective and knowledge. It can be measured by the number of guest speakers, the number of attendance to innovation events (seminar, conference), number of company visited, rotation into other subsidiaries and learned from benchmarking with the best practices company. However, innovation is not just generated internally. Many innovations arise, and innovative organizations seek inspiration by learning from others.

4. Corporate culture means the company vision, mission, rules, policy and leadership style that encouraged innovation. Steen (2009) defined innovation culture as the development of the characteristic to encouraged innovation in organization. This can be measured both qualitative and quantitative : whether they have any incentive and reward, whether there is innovation in their strategy or corporate culture, support from the leader to do innovation, percentage of workforce time that is currently dedicated to innovative projects, number of staff involved in an innovation project (APSII, 2011; Muller et al., 2005; NESTA, 2008). We include Borins (2001) variables to measure innovation capability in corporate culture: support from the top, rewards and awards, and innovation is the responsibility of every employee.

5. Tangible assets that measure in here are infrastructure, technology, IT and capital budget. Indicators to measure this variable are the novelty of technology and IT, the condition of infrastructure, and the amount of investment for innovative projects.

6. Demand from stakeholder means the wished or pressure from stakeholder to company to do innovation. Stakeholder in here means person and organization that affected or can be affected by the company, such as customer, supplier, employee, investor, government \& communities. It can be measured by indicators: previous employee satisfaction, previous public satisfaction, the change of government policy, pressure from citizen and employee, and etc.

Process: We defined process as research and design process to produce innovation, how to convert an idea into something feasible. Saunila \& Ukko (2012) found that innovation process activities are the same with front end phase. Koen et al (2001) defined front end as unstructured activities to develop new product and process. Those activities consisted of opportunity identification, opportunity analysis, idea genesis, idea selection, and concept and technology development. Not all of the idea can be implemented because of many constraints. The managers must choose the idea carefully, appropriate with the objectives wanted to achieve. In our framework, there are three variables to measure innovation process.

1. Generating ideas variable measure the number of ideas and the origins of innovation ideas (what level staff created the idea).

2. Concept development means the process to convert idea become a feasible project. Indicators that can be used to measure this variable are numbered of ongoing experiments and the risks, time and money that have spent to convert ideas into an implemented project (Muller et al, 2005).

3. Collaboration with other organizations can be measured by the number of collaboration and alliances with other companies (e.g. universities or other organization).

Output: In this paper, we defined output as the result of innovation activities. This variable measure the characteristic of innovation that had been produced and the implementation phase.

1. Innovation output means the characteristic of the innovation result. The indicators are the type of innovation (service, product, or internal process), degree of novelty, and type of innovation based on its change. We include NESTA (2008) definition of innovation to measure the degree of novelty: newto world, new to nation or region, new to industry or new-to firm. Whereas, the level of desired changes generated from innovation can be differentiated by incremental and radical. 
2. Implementation process means the process to introduce innovation to public or employee. The indicators are the number of innovative ideas implemented, the number of ideas that failed to be implemented, the ratio of successful ideas to submitted ideas, time and money that have spent to implement the improvement.

Outcomes: We defined outcomes as the result from implementing innovations. Innovation can influence sales, market share, or company productivity and efficiency (OECD, 2005). According to Saunila \& Ukko (2012), innovation not always affecting economic value but also improve working environment.

1. Organizational performance means the company perceived impact from implementing innovation. Albury (2005) stated that the successful innovation should improve the efficiency and effectiveness. The indicators to measure organizational performance are the degree of efficiency, effectiveness, and productivity improvement, also winning innovative prizes awarded.

2. Particular innovation objective means the particular target of each innovation that was determined at the beginning. Indicators to measure this aspect are percentage of targets has been achieved and how long did it take (NESTA, 2008).

3. Stakeholder impact such as customer satisfaction, employee satisfaction, societal impact, and other intangible aspect (e.g. Trust and legitimacy). Societal impact means how the innovation affected the society, for example, if there is against from society because of the innovation harmed them.

4. d. Environmental impact measured the positive or negative impact of its innovation such as the waste, and efficiency energy. Whether it gave the improvement in environmental condition, or it made worse.

\section{Conclusion and Recommendation}

This paper developed a conceptual framework to measure innovation performance in public services. The Measurement is based on innovation activity that classified into input, process, output and outcomes. We combined the various indicators of previous research and developed new variables for each input, process, output and outcomes. Input means the factors that make it possible for the firm to create innovations. Input consisted of: diversity, learning from outside, corporate culture, consultancy and alliance, tangible assets (fund, infrastructure and technology), and demand from the stakeholder. Process means the research and design process to convert an idea into feasible innovation. The variable consists of generating idea, concept development and collaboration. Output innovation consisted of the type of innovation and the implementation process. Outcomes refer to the impact that organizational, stakeholder and environmental feel after innovation is implemented. This framework assesses both quantitative and qualitative aspects. Qualitative method is used for measuring intangible aspect like corporate culture, leadership and the impact. Whereas, the quantitative method is used to measure the tangible aspects like innovation budget, time and cost that have been spent, and efficiency. Finally, this research offers the framework for measuring innovation performance started from input until the outcomes. Thus, the managers can trace how the innovation can be success and how it can be failed. The recommendation for further research would be the analysis how each variable affect the innovation performance. Statistical approach is needed to know whether the variable is really valid to measure innovation performance or not. It also needs to analyze how public service sector measure their innovation performance and their difficulties to measure it.

\section{References}

Albury, D. (2005). Fostering Innovation in Public Services. Public Money \& Management, 25(1), 51-56.

APSII. (2011). Working Towards a Measurement Framework for Public Sector Innovation in Australia. Department of Innovation Industry, Science and Research Australian Government. Retrieved from : http://innovation.govspace.gov.au/files/2011/08/ APSII-Draft-Discussion-Paper.pdf.

Bloch, C. (2010). Measuring Public Innovation in the Nordic Countries (MEPIN). Denmark: The Danish Centre for Studies in Research and Research Policy Aarhus University. Retrieved from http://www.nyskopunarvefur.is/sites/www.nyskopunarvefur.is/ files/ filepicker/9/ $201102_{-}$ mepin_report_web.pdf.

Borins, S. (2001). Encouraging Innovation in The Public Sector. Journal of Intellectual Capital, 2(3), 310319. 
Kolk, M., Kyte, P., Oene, F. V. \& Jacobs, J. (2012). Innovation: Measuring it to Manage it. Prism Article Arthur d Little. Retrieved from http://www.adlittle.com/downloads/ tx_adlprism/Prism_0112_Innovation.pdf.

EPSIS. (2012). European Public Sector Innovation Scoreboard (EPSIS) - Methodology Report. Retrieved from http://ec.europa.eu/enterprise/policies/innovation/files/epsis/ methodologyreport_en.pdf.

Gama, N., Silva, M. M. \& Ataide, J. (2006). Innovation Scoreboard: A Balanced Scorecard for Measuring The Value Added by Innovation. Digital Enterprise Technology. Retrieved from http://ltodi.est.ips.pt/det2006/papers/Enterprise/f108_Nelson_Gama_E9.pdf

Koen, P., Ajamian, G., Burkart, R., Clamen, A., Davidson, J., D’Amore, R., Elkins, C., Herald, K., Incorvia, M., Johnson, A., Karol, R., Seibert, R., Slavejkov, A. \& Wagner, K. (2001). Providing clarity and a common language to the fuzzy front end, Research Technology Management, 44(2), 46-55.

Muller, A., Välikangas, L. \& Merlyn, P. (2005). Metrics for Innovation: Guidelines for Developing a Customized Suite of Innovation Metrics. Strategy \& Leadership , 33(1), 37-45.

Neely, A., Bourne, M. \& Kennerley, M. (2000). Performance measurement system design: developing and testing a process-based approach. International Journal of Operations \& Production Management, 20(10), 1119-1145.

NESTA. (2008). Innovation in Government Organizations, Public Sector Agencies and Public Service NGOs. London: Nesta. Retrieved from http://www.nesta.org.uk/ library/documents/innovationindex.pdf

OECD/Eurostat. (2005). Oslo Manual - Guidelines for Collecting and Interpreting Innovation Data. Third Edition. Retrieved from http://www.oecd.org/dataoecd /35/61/2367580.pdf

Radnor, Z. J. \& Barnes, D. (2007). Historical Analysis of Performance Measurement and Management in Operations Management. International Journal of Productivity and Performance Management , 56 (5/6), 384-396.

Rose, S., Shipp, S., Lal, B. \& Stone, A. (2009). Frameworks for Measuring Innovation: Initial Approaches. Athena Alliance . Retrieved from http://www.athenaalliance.org/ pdf/ InnovationFrameworksSTPI.pdf

Saunila, M. \& Ukko, J. (2012). A Conceptual Framework for The Measurement of Innovation Capability and its Effects. Baltic Journal of Management, 7(4), 355-375.

Steen, B. V. (2009). Measuring Innovation in The BC Public Sector : Developing a Performance Measurement Framework for IGRS' Innovation Program. Retrieved from http://dspace.library.uvic.ca:8080/bitstream/handle/1828/1901/vander\%20steenf_ ben. pdf? sequence $=1$. 